ISSN 0103-8478

\title{
Increase in biofilm formation by Escherichia coli under conditions that mimic the mastitic mammary gland
}

\author{
Aumento na formação de biofilmes por Escherichia coli em \\ condições que mimetizam a glândula mamária mastítica
}

\begin{abstract}
João Carlos Miguel Costa ${ }^{\mathrm{I}}$ Isis de Freitas Espeschit ${ }^{\mathrm{I}}$ Fábio Alessandro Pieri Laércio Anjos Benjamin ${ }^{\mathrm{I}}$ Maria Aparecida Scatamburlo Moreira ${ }^{\mathrm{I}^{*}}$
\end{abstract}

\section{ABSTRACT}

Bacterial biofilms are involved in the aggravation and recurrence of clinical mastitis in dairy herds. Several factors such as $\mathrm{pH}$, temperature, concentration of $\mathrm{O}_{2}$ and glucose can affect their induction and growth rates. In this study, biofilm production was demonstrated by 27 Escherichia coli strains isolated from bovine mastitis at different $\mathrm{pH}$ values depending on the availability of glucose, mimicking conditions found in mammary glands affected by the disease. Biofilm formation was analyzed by spectrophotometric analysis in microtiter plate with 16 different culture media and by scanning electron microscopy. Biofilm formation was greater in isolates cultured under conditions associated with low glucose availability (0.5\% or $1.5 \%)$ and with either an acidic (5.5) or alkaline (8.5) $\mathrm{pH}$, compared to conditions associated with high glucose availability (2.5\% or $3.5 \%)$ and near-neutral $p H$ (6.5 or 7.5). Results indicate possible favoring of biofilm production in the later stages of the infectious process caused by $\boldsymbol{E}$. coli, when the gland environment is less propitious to bacterial growth due to the stress conditions mentioned above; contrasting with the environment of the healthy mammary gland, in which there is no limitation on nutrients or conditions of particular alkalinity or acidity. Thus, knowledge of the stage in which is the infection and environmental conditions of the mammary gland that cause increased production of biofilms is of paramount importance to guide the most appropriate control strategies to prevent relapse after treatment of bovine mastitis, an economically important disease in dairy cattle worldwide.

Key words: mammary gland, Escherichia coli, milk, acidity, sugar.

RESUMO

Biofilmes bacterianos estão envolvidos no agravamento e recorrência de mastite clínica em rebanhos leiteiros. Vários fatores, tais como o $\mathrm{pH}$, temperatura, concentração de $\mathrm{O}_{2}$ e glicose podem afetar sua indução e suas taxas de crescimento. Neste estudo, a produção de biofilme foi demonstrada por 27 isolados de Escherichia coli de mastite bovina a valores de $p H$ diferentes, dependendo da disponibilidade de glucose, simulando as condições encontradas nas glândulas mamárias afetadas pela doença. A formação de biofilme foi analisada por espectrofotometria em microplaca com 16 diferentes meios de cultura e por microscopia eletrônica de varredura. A formaçãa de biofilmes foi maior em isolados cultivados em condições associadas com baixa disponibilidade de glucose $(0,5 \%$ ou $1,5 \%)$ tanto com pH ácido $(5,5)$ como alcalino $(8,5)$, em comparação com as condições associadas com a disponibilidade de alto teor de glucose $(2,5 \%$ ou $3,5 \%)$ e $p H$ próximo à neutralidade $(6,5$ ou 7,5$)$. Os resultados indicam o possível favorecimento da produção de biofilmes em fases posteriores do processo infeccioso de mastite causada por E. coli, quando o ambiente da glândula é menos propício ao crescimento bacteriano devido às condições de estresse acima mencionados, em contraste com o ambiente da glândula mamária saudável, no qual não há nenhuma limitação de nutrientes ou condições de alcalinidade ou acidez em particular. Ainda, o conhecimento da fase em que se encontra a infecção $e$ as condições ambientais da glândula que causariam maior produção de biofilmes é de grande importância para orientar as estratégias de controle mais adequadas para prevenir recidivas após o tratamento da mastite bovina, uma doença economicamente importante na bovinocultura leiteira em todo o mundo.

Palavras-chave: glândula mamária, bactéria, leite, acidez, açúcar.

\section{INTRODUCTION}

Biofilms are highly organized communities of microorganisms structured within an array of exopolysaccharides (EPS), and adhering to a living or inert surface with the function of protecting the

IDepartamento de Veterinária, Universidade Federal de Viçosa (UFV), 36570-000, Viçosa, MG, Brasil. Email: masm@ufv.br.*Autor para correspondência. 
microorganisms in stress environments. The sessile cells arranged in biofilms tend to be more resistant to antimicrobial therapy compared with planktonic free cells, due to the slow diffusion of the antimicrobial in the inner layers of the biofilm (MELCHIOR et al., 2006). They are associated with antimicrobial treatment failure (COSTERTON et al., 1999; MELCHIOR et al., 2006). Several environmental and nutritional factors, besides the presence of sub-inhibitory concentrations of an antimicrobial, can influence biofilm formation by bacterial cells (MELCHIOR et al., 2006; COSTA et al., 2012). Preview study have shown that environments rich in sugars did not favor adhesion and subsequent biofilm formation by Streptococcus sp., while alkaline environments triggered greater adhesion by group B Streptococcus (KAUR et al., 2009).

Bovine mastitis is considered the most significant disease of dairy cattle in the world (STEENEVELD et al., 2011). It is estimated that losses of billions of liters of milk per year occur due to this disease, making it of great concern for the dairy sector worldwide (HUIJPS et al., 2009). Escherichia coli is a leading microorganism involved in cases of mastitis, and is strongly associated with clinical infection (STEENEVELD et al., 2011). However, it has been demonstrated that some strains of $\boldsymbol{E}$. coli have greater ability to adhere to and replicate in breast tissue and may lead to persistent infections in the host (DOGAN et al., 2006; FONTAINE \& SMITH, 2006). The mastitis treatment is based primarily on intramammary administration of antimicrobial agents to the animal, which may also be delivered by the parenteral route depending on the severity of the case. However, studies have shown that in many cases the success of the therapy is frustrated, being unable to eliminate the agent from the mammary gland, and allowing the development of persistent and recurrent cases of the disease (MELCHIOR et al., 2007; SIMOJOKI et al., 2012). One hypothesis to explain this fact is the ability of some microorganisms to form biofilms on the surface of mammary gland tissue, thus presenting resistance to several antimicrobials (MELCHIOR et al., 2006).

The mechanisms by which sessile cells become resistant can be attributed to several factors, among them phenotypic changes in bacterial cells in biofilms, inactivation of antimicrobials by EPS, the physical barrier exerted by the EPS matrix and nutrient limitation, reducing the bacterial growth rate (CLUTTERBUCK et al., 2007). Moreover, distribution of an antimicrobial in the breast tissue can be blocked by pathophysiologic changes in the mammary gland such as ischemia and necrosis, leaving the antimicrobial either unable to reach the site of action or arriving at sub-inhibitory concentrations (BENGTSSON et al., 2009).

The fermentation by microorganisms in infected mammary gland makes that concentrations of lactose and glucose achieve lower levels than normal. As $\boldsymbol{E}$. coli breaks down the lactose in galactose and glucose in raw milk and this last is the main carbohydrate used by this bacteria, lower levels of glucose could provide a stressful environment to the bacteria which could result in increased production of biofilms during specific phases of the disease (ANDREWS et al., 2008).

Given the economic implications for the cattle industry in Brazil and worldwide, the increasing numbers of mastitis caused by $\boldsymbol{E}$. coli and the possible involvement of biofilms in persistent and/or recurrent cases of the disease, knowledge of factors that may influence their production are essential for establishing more effective treatment strategies.

This study aimed to evaluate biofilm formation by isolates of $\boldsymbol{E}$. coli obtained from bovine mastitis under conditions of different $\mathrm{pH}$ and glucose availability, mimicking conditions found in mammary glands affected by the disease.

\section{MATERIAL AND METHODS}

Twenty-seven isolates of $\boldsymbol{E}$. coli biofilm producers obtained from mastitic milk belonging to Brazilian Agricultural Research Corporation, EMBRAPA - Dairy Cattle and the Laboratory of Bacterial Diseases of the Veterinary Medicine Department of the Federal University of Viçosa, were used. The isolates were stored in microtubes containing Brain Heart Infusion broth (BHI, Oxoid, Cambridge, England) supplemented with $20 \%$ glycerol and stored at $-80^{\circ} \mathrm{C}$ until use.

We prepared 16 different minimal culture media (MM) associating four glucose concentrations to four $\mathrm{pH}$ values (Table 1). These MM were comprised of a carbon source at different concentrations (glucose - Table 1) a nitrogen source (peptone 10g) and a salt (sodium chloride 5g) and distilled water $(1000 \mathrm{ml})$. The isolates were reactivated in each $\mathrm{MM}$ and incubated at $37^{\circ} \mathrm{C}$ for 24 hours. The detection of biofilm formation was realized according STEPANOVIĆ et al. (2000) with modifications. The cultures were diluted to a concentration of $1.0 \times 10^{8} \mathrm{CFU}$ $\mathrm{ml}^{-1}$, and $300 \mu \mathrm{L}$ of the diluted culture were added to the wells of microtiter plates (Nunc-limmuno plates, Denmark), and incubated at $37^{\circ} \mathrm{C}$ for $24 \mathrm{~h}$. The production of biofilms was analyzed by optical 
Table 1 - Different culture media, used to analyze biofilm production by Escherichia coli isolates from mastitic milk.

\begin{tabular}{lcc}
\hline Minimum media & Glucose $(\%)$ & $\mathrm{pH}$ \\
\hline A1 & 2.5 & 5.5 \\
A2 & 2.5 & 6.5 \\
A3 & 2.5 & 7.5 \\
A4 & 2,5 & 8.5 \\
B1 & 0.5 & 5.5 \\
B2 & 0.5 & 6.5 \\
B3 & 0.5 & 7.5 \\
B4 & 0.5 & 8.5 \\
C1 & 1.5 & 5.5 \\
C2 & 1.5 & 6.5 \\
C3 & 1.5 & 7.5 \\
C4 & 1.5 & 8.5 \\
D1 & 3.5 & 5.5 \\
D2 & 3.5 & 6.5 \\
D3 & 3.5 & 7.5 \\
D4 & 3.5 & 8.5 \\
\hline
\end{tabular}

density readings (OD550) in an absorbance microplate reader (Bio tek ELx800, Winooski, EUA), comparing the values of the samples with those of the negative control. All procedures were performed in triplicate. In addition to the 16 tested media two MM, one without glucose and the other non-inoculated as a sterilization control, were also set up for comparison purposes.

Scanning electron microscopy (SEM) was used to visualize the typical architecture of biofilms formed in different MM, according to the methodology of ABDI-ALI et al. (2006). The SEM was performed for four randomly selected isolates (two weak and two strong biofilm producers identified by $\mathrm{OD}$ ) grown under conditions favoring higher and lower production of biofilms. Were prepared polystyrene slides measuring $1.0 \times 0.5 \mathrm{~cm}$, simulating the surface of the microtiter plates used. These slides were placed in glass tubes containing $5 \mathrm{~mL}$ culture of each isolate in BHI broth at $1.0 \times 10^{8} \mathrm{CFU}$ $\mathrm{mL}^{-1}$ and they were incubated at $37^{\circ} \mathrm{C}$ for 24 hours. Slides were fixed in $2.5 \%$ glutaraldehyde in $0.1 \mathrm{M}$ phosphate buffer, $\mathrm{pH} 7.2$ for a period of 24 hours at a temperature of $4^{\circ} \mathrm{C}$. After fixation a post-fixation was carried out in $1 \%$ osmium tetroxide for 2 hours to $4^{\circ} \mathrm{C}$, dehydration and critical point drying Balzers CPD 020, mounting support and cover with aluminum gold "sputter coater" (Balzers ACS 010). Subsequently, the material was analyzed by SEM Leo 1430VP with increasing magnitudes.

The results were submitted to analysis of variance (ANOVA) and a comparison of biofilm production in the different media conditions was performed using the Minitab 15 software package, employing the Kruskal-Wallis test followed by Dunn's test for multiple comparisons. For both tests, differences were considered significant when $\mathrm{P}<0.05$.

\section{RESULTS}

All isolates were able to attach and form biofilms, though in different numbers and with different biomasses, in all tested MM. These results are presented in a boxplot graph with the distribution of biofilm production of these $27 \boldsymbol{E}$. coli isolates in all tested MM (Figure 1). The results were clustered into three groups based on biofilm production: Group 1 (high production), Group 2 (intermediate production) and Group 3 (low production).

In culture media A2, A3, D2 and D3 (Group 3) the combination of a $\mathrm{pH}$ close to neutral ( $\mathrm{pH} 6.5$ or 7.5 ) and a high glucose concentration $(2.5 \%$ or $3.5 \%)$, appeared to exert an antagonistic effect, resulting in reduced production of biofilms by the bacteria (Figures 1 and 2). Biofilm production was significantly higher $(\mathrm{P}<0.001)$ for the $\mathrm{B} 1$ and B4 media (Group 1). In this case the association between a reduced availability of glucose $(0.5 \%$ or $1.5 \%)$ at $\mathrm{pH}$ values further from neutral $(\mathrm{pH} 5.5$ or $8.5)$, provided stress conditions to the bacterial cells and favored greater biofilm production (Figures 1 and 2). Culture media A1, A4, B2, B3, C1, C4, D1 and D4 (Group 2) also triggered a considerable increase in biofilm production, however less than those in Group 1. In this case just one of the factors, either $\mathrm{pH}$ or glucose availability, provided a stressful environment to the bacteria. These data confirm that $\mathrm{pH}$ (5.5 and $8.5)$ or glucose $(0.5 \%$ and $1.5 \%)$ individually influence the production of biofilms by $\boldsymbol{E}$. coli and when they are associated there seems to be a synergistic effect, giving an increased production (Figure 1).

An atypical case was found for C2 and C3 in that although they had low availability of glucose $(1.5 \%)$, their outcomes were statistically equivalent to biofilm production by Group $3(\mathrm{P}>0.05)$. There were statistical differences in the ability to form biofilms between Groups 1, 2 and $3(\mathrm{P}<0.001)$. The same was true when comparing Group 2 with Group 3 $(\mathrm{P}<0.001)$. However, no difference was found when comparing the means between each medium within a group $(\mathrm{P}>0.05)$.

Through SEM was possible to visualize a higher biomass formation of biofilms under conditions that provided greater biofilm formation (Figure 2) identified by spectrophotometric analysis, 


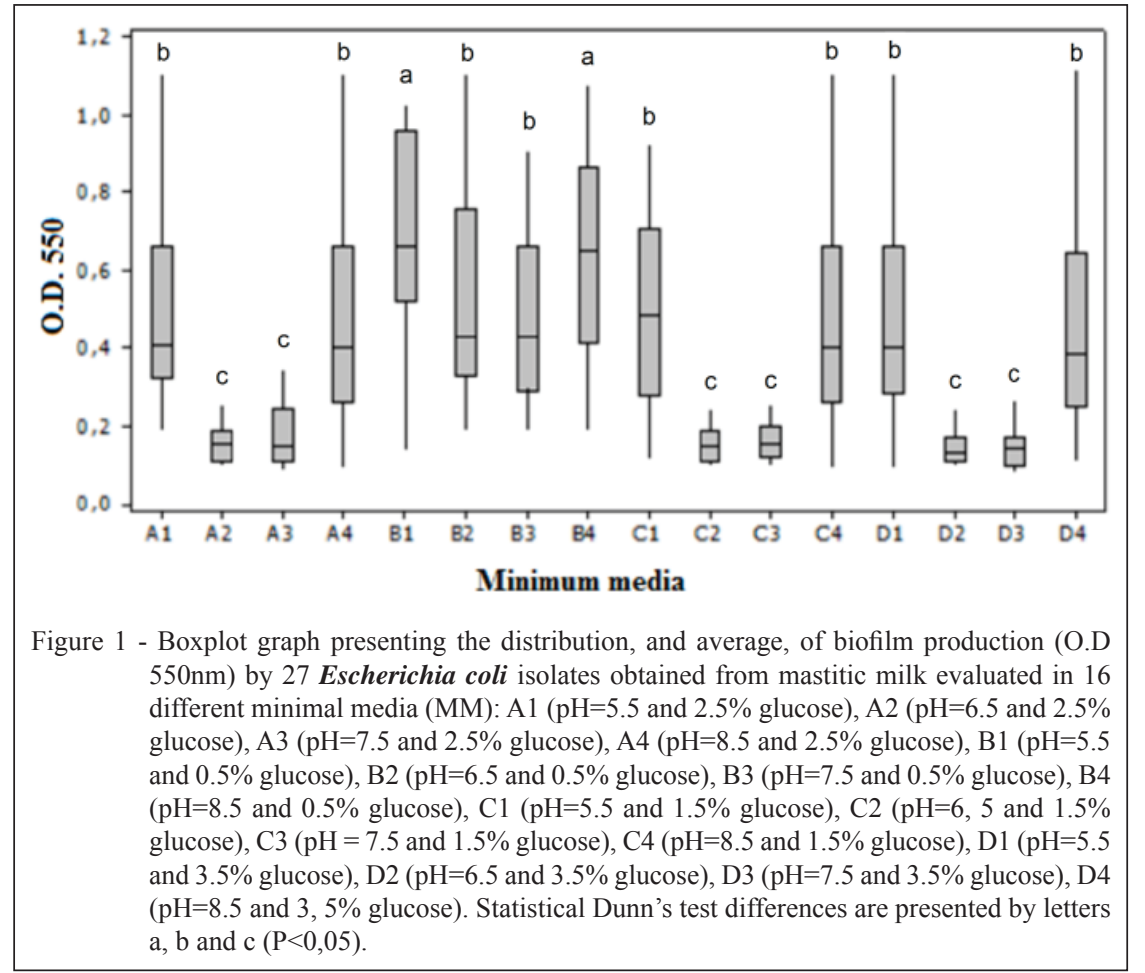

showing good correlation between the results of the two techniques.

\section{DISCUSSION}

In a similar study KAUR et al. (2009) found that Group B streptococci isolated from clinical cases of vaginitis in humans produced large quantities of biofilms in alkaline media with limited glucose compared to acidic or neutral media rich in glucose. In another study, MICHU et al. (2011) observed increased production of biofilms by isolates of Staphylococcus epidermidis grown in media with lower concentrations of glucose compared to isolates cultured in higher concentrations.

The differences in the production of biofilms under different environmental and nutritional conditions are possibly explained by the ability of some microorganisms to respond to external stimuli, such as population density, limiting nutrients, osmolarity, $\mathrm{pH}$ or composition of the medium, activating genes responsible for the expression of surface proteins that promote adhesion and the production of EPS directly involved in the production of biofilms (FRANK et al., 2007).

The results also reveal that the culture media that most favor the production of biofilms, Group 1, have similar conditions as the mammary gland in the later stages of inflammation, after the onset of clinical signs. The $\mathrm{pH}$ of the gland lumen may vary from alkaline to acidic as the disease progresses (VANGROENWEGHE et al., 2005; ANDREWS et al., 2008). According to ANDREWS et al. (2008), at the start of clinical symptoms, the $\mathrm{pH}$ tends to be high due to large amounts of alkalizing substances produced by the body to offset the acidity produced by bacterial fermentation. Moreover, at this stage, high levels of immune cells from the plasma reach the lactiferous alveoli through the bloodstream, which increase the $\mathrm{pH}$ due to the alkaline nature of the plasma, reaching a maximum of 8.3 to 8.7. As the infectious process progresses, larger amounts of acids are produced from inflammation and fermentation of sugars by bacteria, causing the $\mathrm{pH}$ to decrease and reaching near 5 (VANGROENWEGHE et al., 2005; ANDREWS et al., 2008). Such fermentation by microorganisms also makes the concentrations of glucose and lactose in the lumen of the mammary gland affected by the disease achieve lower levels than normal, near $0.5 \%$ (ANDREWS et al., 2008), values that tested at work, showed greater production of biofilms. It is important to highlight that the MM that were less favorable to the production of biofilms (Group 3) had conditions similar to the environment of healthy mammary gland, rich in sugar and with $\mathrm{pH}$ values close to neutrality (RADOSTITS et al., 2007; ANDREWS et al., 2008). 


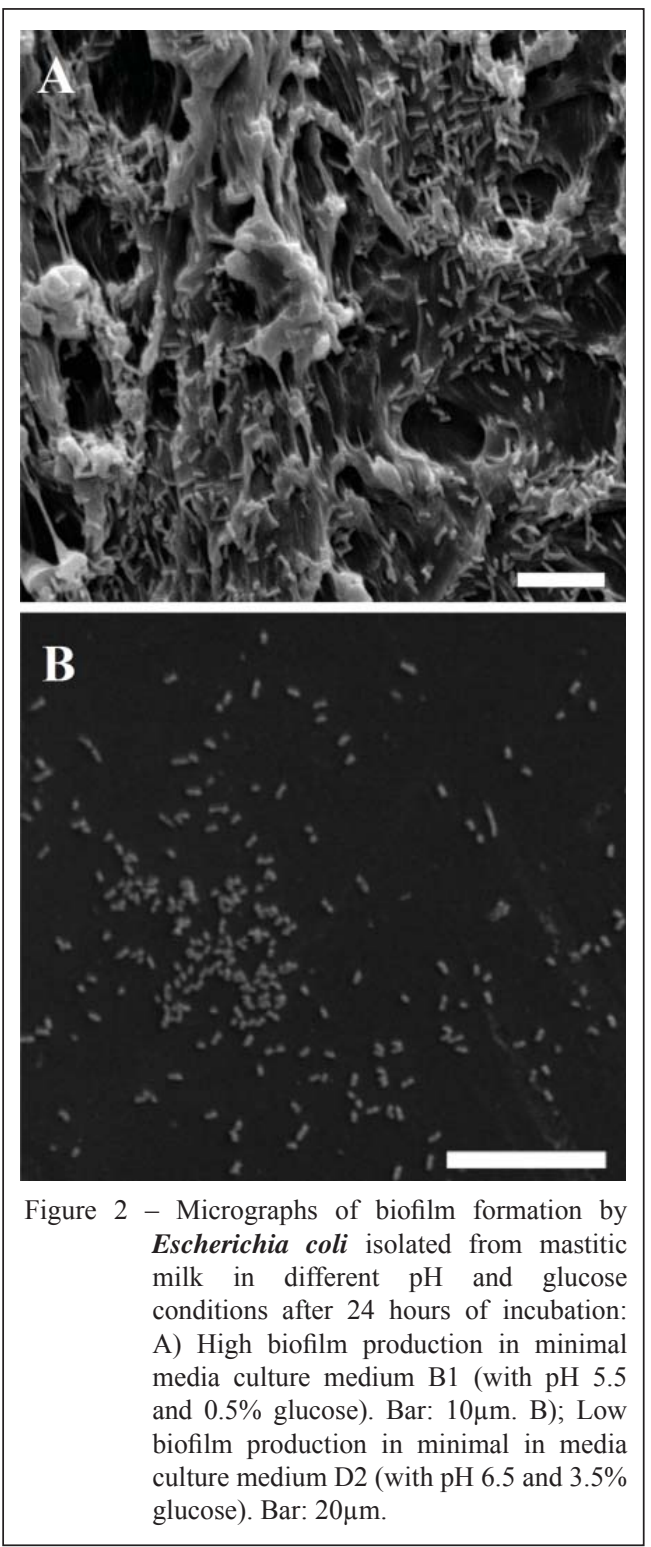

Thus the results indicate possible favoring of the production of biofilms in later stages of the infectious process in mastitis caused by $\boldsymbol{E}$. coli, when the gland environment is less propitious to bacterial growth due to the stress conditions mentioned above, in contrast to the environment of the healthy mammary gland, in which there is no limitation on nutrients or conditions of particular alkalinity or acidity. Thus, knowledge of the stage in which is the infection and environmental conditions of the mammary gland that cause increased production of biofilms is of paramount importance to guide the most appropriate control strategies to prevent relapse after treatment of bovine mastitis, an economically important disease in dairy cattle worldwide.

\section{ACKNOWLEDGEMENTS}

The authors thank the Fundação de Amparo à Pesquisa em Minas Gerais (FAPEMIG), Conselho Nacional de Desenvolvimento Científico e Tecnológico (CNPq) and Coordenação de aperfeiçoamento de Pessoal de Nível Superior (CAPES) for financial support, and Dr. Maria Aparecida Vasconcelos Paiva Brito (Brazilian Agricultural Research Corporation, EMBRAPA - Dairy Cattle) for providing some $\boldsymbol{E}$. coli isolates from clinical mastitis.

\section{REFERENCES}

ABDI-ALI, A. et al. Bactericidal activity of various antibiotics against biofilm-producing Pseudomonas aeruginosa. International Journal of Antimicrobial Agents, v.27, p.196-200, 2006. Available from: <http://www.sciencedirect.com/science/article/ 
pii/S0924857905003250>. Accessed: aug. 1, 2013. doi: 10.1016/j. ijantimicag.2005.10.007

ANDREWS, A.H. et al. Bovine Medicine: Diseases and Husbandry of Cattle. São Paulo, Roca, 2008.

BENGTSSON, B. et al.Antimicrobial susceptibility of udder pathogens from cases of acute clinical mastitis in dairy cows. Veterinary Microbiology, v.136, p.142-149, 2009. Available from: <http:// www.sciencedirect.com/science/article/pii/S0378113508005014>. Accessed: aug. 1, 2013. doi: 10.1016/j.vetmic.2008.10.024.

CLUTTERBUCK, A.L. et al. Biofilms and their relevance to veterinary medicine. Veterinary Microbiology, v.121, p.1-17, 2007. Available from: <http://www.sciencedirect.com/science/ article/pii/S037811350600527X $>$. Accessed: aug. 1, 2013. doi: 10.1016/j.vetmic.2006.12.029.

COSTA, J.C.M. et al. Increased production of biofilms by Escherichia coli in the presence of enrofloxacin. Veterinary Microbiology, v.160, p.488-490, 2012. Available from: <http:// www.sciencedirect.com/science/article/pii/S0378113512003458>. Accessed: aug. 1, 2013. doi: 10.1016/j.vetmic.2012.05.036.

COSTERTON, J.W. et al. Bacterial biofilms: A common cause of persistent infections. Science, v.284, p.1318-1322, 1999. Available from: <http://www.sciencemag.org/content/284/5418/1318.long >. Accessed: aug. 1, 2013. doi: 10.1126/science.284.5418.1318.

DOGAN, B. et al. Adherent and invasive Escherichia coli are associated with persistent bovine mastitis. Veterinary Microbiology, v.116, p.270-282, 2006. Available from: <http:// www.sciencedirect.com/science/article/pii/S0378113506001696>. Accessed: aug. 1, 2013. doi: 10.1016/j.vetmic.2006.04.023.

FONTAINE, M.C.; SMITH, D.G.E. Microbial biofilms: Does breaking the microbes' community spirit hold the key to beating persistent mastitis? Veterinary Journal, v.171, p.387-388, 2006. Available from: <http://www.sciencedirect.com/science/article/ pii/S1090023305001048>. Accessed: aug. 1, 2013. doi: 10.1016/j. tvj1.2005.04.008.

FRANK, K.L. et al. In vitro effects of antimicrobial agents on planktonic and biofilm forms of Staphylococcus lugdunensis clinical isolates. Antimicrobial Agents and Chemotherapy, v. 51 , p.888-895, 2007. Available from: <http://www.ncbi.nlm.nih.gov/ pmc/articles/PMC1803120/pdf/1052-06.pdf>. Accessed: aug. 1, 2013. doi: 10.1128/AAC.01052-06.

HUIJPS, K. et al. Preferences of cost factors for mastitis management among Dutch dairy farmers using adaptive conjoint analysis. Preventive Veterinary Medicine, v.92, p.351-359, 2009 Available from: <http://www.sciencedirect.com/science/article/ pii/S0167587709002529>. Accessed: aug. 1, 2013. doi: 10.1016/j. prevetmed.2009.08.024
KAUR, H. et al. Biofilm formation in clinical isolates of group B streptococci from north India. Microbial Pathogenesis, v.46, p.321-327, 2009. Available from: <http://www.sciencedirect.com/ science/article/pii/S0882401009000515>. Accessed: aug. 1, 2013. doi: 10.1016/j.micpath.2009.04.004

MELCHIOR, M.B. et al. Extended antimicrobial susceptibility assay for Staphylococcus aureus isolates from bovine mastitis growing in biofilms. Veterinary Microbiology, v.125, p.141-149, 2007. Available from: <http://www.sciencedirect.com/science/ article/pii/S0378113507002647>. Accessed: aug. 1, 2013. doi: 10.1016/j.vetmic.2007.05.019

MELCHIOR, M.B. et al. Biofilms: A role in recurrent mastitis infections? Veterinary Journal, v.171, p.398-407, 2006. Available from: <http://www.sciencedirect.com/science/article/ pii/S1090023305000316>. Accessed: aug. 1, 2013. doi: 10.1016/j. tvj1.2005.01.006.

MICHU, E. etal. Biofilm formation on stainless steel by Staphylococcus epidermidis in milk and influence of glucose and sodium chloride on the development of ica-mediated biofilms. International Dairy Journal, v.21, p.179-184, 2011. Available from: <http://www. sciencedirect.com/science/article/pii/S095869461000227X>. Accessed: aug. 1, 2013. doi: 10.1016/j.idairyj.2010.10.004.

RADOSTITS, O.M. et al. Veterinary medicine. A textbook of the diseases of cattle, horses, sheep, pigs and goats, 10th Edition. London, Saunders, 2007.

SIMOJOKI, H. et al. Is the biofilm formation and slime producing ability of coagulase-negative staphylococci associated with the persistence and severity of intramammary infection? Veterinary Microbiology, v.158, p.344-352, 2012. Available from: <http:// www.sciencedirect.com/science/article/pii/S0378113512001411>. Accessed: aug. 1, 2013. doi: 10.1016/j.vetmic.2012.02.031.

STEENEVELD, W. et al. Cow-specific treatment of clinical mastitis: An economic approach. Journal of Dairy Science, v.94, p.174-188, 2011. Available from: <http://www.sciencedirect.com/ science/article/pii/S0022030210006867>. Accessed: aug. 1, 2013. doi: $10.3168 /$ jds.2010-3367.

STEPANOVIĆ, S. et al.Amodified microtiter-plate test for quantification of staphylococcal biofilm formation. Journal of Microbiological Methods, v.40, p.175-179, 2000. Available from: <http://www. sciencedirect.com/science/article/pii/S0167701200001226>. Accessed: aug. 1, 2013. doi: 10.1016/S0167-7012(00)00122-6.

VANGROENWEGHE, F. et al. Physiology of the periparturient period and its relation to severity of clinical mastitis. Domestic Animal Endocrinology, v.29, p.283-293, 2005. Available from: <http:// www.sciencedirect.com/science/article/pii/S0739724005000615>. Accessed: aug. 1, 2013. doi: 10.1016/j.domaniend.2005.02.016. 